\title{
Effect of Fluoride Gels on Microhardness and Surface Roughness of Bleached Enamel
}

\author{
Ana L.P. China ${ }^{1}$, Nayara M. Souza ${ }^{1}$, Yasmin do S. B. de L. Gomes ${ }^{1}$, Larissa D. Alexandrino ${ }^{1}$ and \\ Cecy M. Silva ${ }^{2, *}$ \\ ${ }^{I}$ Student, School of Dentistry, Federal University of Para, Para, Brazil \\ ${ }^{2}$ School of Dentistry, Federal University of Para, Para, Brazil
}

\begin{abstract}
The effect of bleaching treatments containing added calcium and combined with neutral or acidic fluoride gels on tooth enamel was investigated in vitro through Knoop microhardness (KHN) and surface roughness (SR) measurements. A total of 60 bovine incisors were tested, including 30 for SR measurements and 30 for KHN measurements. The specimens were divided into 12 groups and subjected to a bleaching agent with hydrogen peroxide $35 \%$ (Whiteness HP 35\% Maxx, FGM) or hydrogen peroxide 35\% with calcium (Whiteness HP 35\% Blue Calcium, FGM) and a fluoride treatment flugel acidulated phosphate fluoride (APF) or flugel neutral fluoride (NF). Control specimens were submitted to bleaching treatments without fluoride. Microhardness tests were performed using a Knoop indentor. Roughness measurements were obtained using a roughness analyzer. Measurements were obtained before and after treatment. The specimens were stored in distilled water at $37^{\circ} \mathrm{C}$ between treatments. The results were analyzed using descriptive and inferential statistics. Treatments using APF combined with $35 \%$ HP caused a decrease in microhardness, while NF combined with HP $35 \% \mathrm{Ca}$ increased the enamel hardness. Fluoride gels did not alter the SR of the bleached enamel.
\end{abstract}

Keywords: Dental Enamel, Flugel, Microhardness, Peroxides, Roughness, Tooth Bleaching.

\section{INTRODUCTION}

Concerns about appearance, the availability of new procedures, and media influences have increased public interest in tooth whitening. This in turn has driven advances in cosmetic dentistry and encouraged research in this area [1]. Bleaching agents have been used for more than a century and have increased in popularity with the advent of home whitening techniques, which provide convenience and lower costs.

Tooth color changes can come on the enamel surface (extrinsic stain) or inside the tooth structure (intrinsic stain) [2, $3]$. In dentistry, bleaching agents containing peroxide have been used to improve the colour of teeth and remove stain [4-6]. It is important to mention that some structural features and some superficial characteristics of the enamel may contribute to pigment precipitation, such as roughness, porosity, and depression [7].

After bleaching, colouring pigments adhere to the rough surface and cause more discoloration than the original tooth. [8] In particular, a rough enamel surface with the pores or superficial defects after these changes can discolour easily. [3] For these reasons, it is essential that the damaged enamel surface should be recovered after bleaching for a lasting

\footnotetext{
*Address correspondence to this author at the Augusto Correa Street $n^{\circ} 1$, Guamá, Belém, Pa, Brazil, CEP: 66075-110; Tel: +559132521269;

E-mail: cecymsilva@gmail.com
}

bleaching effect [8]. Previous studies have reported that fluoride or casein phosphopeptide-amorphous calcium phosphate (CPP-ACP) recovered the damaged enamel surface and prevented staining [9-14]. It is possible that fluoride contributes to the repair of microstructural defects through the adsorption and precipitation of calcium and phosphate present in saliva [15].

Bleaching occurs owing to the decomposition of peroxide into free radicals, which subsequently react with the large pigment molecules, transforming them into smaller, less pigment molecules and so the hydrogen peroxide (HP) oxidizes a wide variety of organic compound $[1,16,17]$.

Some studies have reported reductions in enamel microhardness following bleaching with peroxide [12, 18-27], while others have reported no change in surface microhardness $[12,28-31]$. Bleaching agents used in the absence of calcium and fluoride ions caused greater mineral loss from the enamel surface [32], and further research on the benefits of adding calcium to bleaching agents is necessary.

Tooth bleaching can also result in increased surface roughness (SR) [26], promoting the adhesion of Streptococcus mutans to tooth enamel [33]. The use of fluoride is important in the remineralization of tooth enamel $[21,24,32$, 34], and fluoride therapy could reduce the deleterious effects of bleaching agents.

This study evaluated the effect of neutral and acidulated phosphate fluoride on Knoop microhardness (KHN) and SR 
Table 1. Summary of experimental groups.

\begin{tabular}{|c|c|c|c|}
\hline Test & Bleaching Agent & Fluoride Therapy & Group \\
\hline \multirow{4}{*}{ KHN } & \multirow{2}{*}{$35 \% \mathrm{HP}^{\mathrm{a}}$} & $\mathrm{S} / \mathrm{F}$ & 1 \\
\hline & & $\mathrm{FFA}^{\mathrm{c}}$ & 3 \\
\hline & \multirow{2}{*}{$35 \%$ HP with $\mathrm{Ca}^{\mathrm{b}}$} & $\mathrm{S} / \mathrm{F}$ & 4 \\
\hline & & FFA & 6 \\
\hline \multirow{4}{*}{ SR } & \multirow[b]{2}{*}{$35 \% \mathrm{HP}$} & $\mathrm{S} / \mathrm{F}$ & 7 \\
\hline & & $\mathrm{NF}$ & 8 \\
\hline & \multirow[t]{2}{*}{$35 \% \mathrm{HP} \mathrm{Ca}$} & $\mathrm{NF}$ & 11 \\
\hline & & FFA & 12 \\
\hline
\end{tabular}

${ }^{a}$ Whiteness HP Maxx, FGM Products Odontol. Ltda., Joinville, SC, Brazil.

${ }^{\mathrm{b}}$ Whiteness HP Blue Calcium, FGM Products Odontol. Ltda., Joinville, SC, Brazil.

${ }^{\mathrm{c}}$ Flugel, DFL Industry and Trade S.A, Jacarepaguá, RJ, Brazil

of enamel bleached using $35 \%$ hydrogen peroxide (HP) with and without added calcium. Our null hypotheses were that neither the $\mathrm{pH}$ of the fluoride gel nor the presence of added calcium would affect KHN or SR of tooth enamel bleached with HP.

\section{METHODOLOGY}

\section{Specimen Preparation}

The use of bovine teeth in this research project was approved by the Ethics Committee for Animal ResearchCEPAN under protocol 004/2011. A total of 60 bovine incisors were obtained and visually inspected to exclude those with stains, cracks, or fractures in the labial surfaces of the enamel. After careful cleaning, the specimens were stored at $4{ }^{\circ} \mathrm{C}$ in distilled water until use.

The surface roughness was tested on a $4 \mathrm{~mm} \times 4 \mathrm{~mm}$ flattened section on the buccal surface of the teeth. The trimmed portion always corresponded to the central area of the coronary labial surface so that the enamel prisms were obtained with the same inclinations. The buccal surfaces were flattened on an APL-4 (AROTEC Ltda, São Paulo, Brazil) polisher using 220, 400, 600, and 1200-grit abrasive paper under running water.

KHN measurements were performed on $4 \times 4 \times 3 \mathrm{~mm}$ thick sections removed from the buccal coronary surfaces using double sided steel discs. The sections were planarized in an APL-4 polisher (AROTEC Ltda, São Paulo, Brazil) using 400, 500, 600, and 1200-grit abrasive paper (3M Brazil, Sumaré, SP, Brazil) under a stream of water. The enamel was polished using a micromotor and felt disc (Diamond Flex, FGM, Joinville, SC, Brazil) impregnated with diamond polishing paste (Diamond Excel, FGM, Joinville, SC, Brazil). A chemically activated acrylic resin lacquer (Vipio Flash / Dental Vipio) was used to embed the samples inside 12 mm-diameter, 2 mm-tall PVC tubes (Akros) so that the labial surface (enamel) remained exposed.

\section{Experimental Groups}

The specimens were randomly divided into 12 groups (n $=10$ samples per group) according to test method, bleaching agent, and fluoride therapy (Table 1).

The samples were bleached during three sessions at intervals of $7 \mathrm{~d}$, totaling $14 \mathrm{~d}$ of bleaching. After each session, the specimens were washed with running water for $1 \mathrm{~min}$. Following washing, NF gel was applied for $4 \mathrm{~min}$ or APF was applied for $1 \mathrm{~min}$. The samples were stored in distilled water at $37{ }^{\circ} \mathrm{C}$ between bleaching sessions. The control groups were subjected to bleaching but not fluoride therapy $(\mathrm{Y} / \mathrm{F})$.

\section{Microhardness Testing}

Six groups of specimens (G1-G6) were subjected to KHN testing which was performed in a Future-Tech Microhardness Tester (Shimadzu Corporation, Kyoto, Japan) before and after treatment. During each measurement, five indentations were made by applying a Knoop indenter under a load of $100 \mathrm{gf}$ for $15 \mathrm{~s}$. The results were subjected to descriptive and inferential statistical analysis (one-way ANOVA and Student's t-test for paired and independent 
Table 2. Initial and final microhardness measurements of enamel samples.

\begin{tabular}{|c|c|c|c|}
\hline \multirow{2}{*}{ Analysis Groups } & Initial & KHN (mean \pm SD) & \multirow{2}{*}{ P } \\
\cline { 2 - 4 } & $259.89 \pm 18.44$ & $205.22 \pm 31.47$ & $.0030^{\mathrm{a}}$ \\
\hline \hline G1 - 35\% HP S/F & $266.37 \pm 27.84$ & $205.33 \pm 31.56$ & $.0540^{\mathrm{a}}$ \\
\hline G2 - 35\% HP FN & $256.2 \pm 13.05$ & $198.06 \pm 28.32$ & $.0111^{\mathrm{a}}$ \\
\hline G3 - 35\% HP FFA & $241.30 \pm 21.41$ & $210.11 \pm 48.06$ & $.2216^{\mathrm{a}}$ \\
\hline G4 - 35\% HP w/ Ca S/F & $271.12 \pm 27.24$ & $283.66 \pm 28.28$ & $.1297^{\mathrm{a}}$ \\
\hline G5 - 35\% HP w/ Ca FN & $225.24 \pm 25.94$ & $196.90 \pm 20.85$ & $.1858^{\mathrm{a}}$ \\
\hline G6 - 35\% HP w/ Ca FFA & & & \\
\hline
\end{tabular}

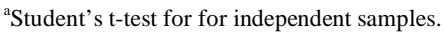

$\mathrm{SD}$, standard deviation.

Table 3. Changes in microhardness for enamel samples.

\begin{tabular}{|c|c|c|}
\hline Analysis Groups & $\begin{array}{c}\text { Mean Change ( } \pm \text { SD) in KHN } \\
\text { From Initial to Final Value }\end{array}$ & p \\
\hline \hline G1 - 35\% HP S/F & $-54.67 \pm 18.98$ & $-0344^{\mathrm{a}}$ \\
\hline G2 - 35\% HP FN & $-61.04 \pm 31.56$ & $-58.14 \pm 29.10$ \\
\hline G3 - 35\% HP FFA & $-31.18 \pm 63.69$ & $12.54 \pm 14.74$ \\
\hline G4 - 35\% HP w/ Ca S/F & $-28.33 \pm 39.71$ & \\
\hline G5 - 35\% HP w/ Ca FN & & \\
\hline G6 - 35\% HP w/ Ca FFA &
\end{tabular}

${ }^{\mathrm{a} O n e-w a y ~ A N O V A}$

$\mathrm{SD}$, standard deviation

samples), using the Microsoft Excel $2010^{\circledR}$ (Microsoft Office package, Microsoft Corporation, Redmond, Washington, USA, 2010) and the BioEstat 5.0 ${ }^{\circledR}$ (Instituto de Desenvolvimento Sustentável Mamirauá - IDSM / MCT / CNPq, Belém, Pará, Brazil, 2007) software packages. The alpha level adopted for rejection of the null hypothesis was $\leq 5 \%$.

\section{Roughness Testing}

Six groups of specimens (G7-G12) were subjected to SR testing. The SR of each sample was measured before and after treatment using a Surftest SJ 201 (Mitutoyo Sul Americana Ltda, São Paulo, Brazil) roughness analyzer. The specimen was mounted horizontally using wax (NewWax 7) and the tip of the analyzer traversed the central $0.25 \mathrm{~mm}$. The average roughness ( $\mathrm{Ra}$ ) was determined from three diametrically opposed measurements. The results were subjected to descriptive and inferential statistical analysis (oneway ANOVA and Student's t-test for paired and independent samples), using the Microsoft Excel $2010^{\circledR}$ (Microsoft Office package, Microsoft Corporation, Redmond, Washington, USA, 2010) and the BioEstat 5.0 ${ }^{\circledR}$ (Instituto de Desenvolvimento Sustentável Mamirauá - IDSM / MCT / CNPq, Belém, Pará, Brazil, 2007) software packages. The alpha level adopted for rejection of the null hypothesis was $\leq 5 \%$.

\section{RESULTS}

\section{Microhardness (G1-G6)}

As shown in Table 2, within-group initial KHN values differed from final KHN values in groups G1 and G3, but not in groups G2, G4, or G5.

There was a significant overall effect of group on magnitude of change in microhardness from the initial to the final measurement (Table 3).

As shown in Table 4, inter-group comparisons of the magnitude of change in microhardness revealed a group difference between the G2 and G5 changes. The G3/G6 and G1/G4 pairs and the G1/G2/G3 and G4/G5/G6 trios, however, showed no significant differences in $\mathrm{KHN}$ changes between compared groups.

\section{Roughness (G7-G12)}

The experimental treatments that produced significant effects on KHN, described above, did not affect roughness of the enamel surface. No significant differences between the initial and final SR measurements were identified for groups G7-G12 (Student's t-test, Table 5). 
Table 4. Group comparisons of microhardness variation.

\begin{tabular}{|c|c|}
\hline KHN Variation Comparison & p \\
\hline \hline $\mathrm{G} 1 \times \mathrm{G} 4$ & $.4736^{\mathrm{a}}$ \\
\hline $\mathrm{G} 2 \times \mathrm{G} 5$ & $.0052^{\mathrm{a}}$ \\
\hline $\mathrm{G} 3 \times \mathrm{G} 6$ & $.2127^{\mathrm{a}}$ \\
\hline $\mathrm{G} 1 \times \mathrm{G} 2 \times \mathrm{G} 3$ & $.9335^{\mathrm{b}}$ \\
\hline $\mathrm{G} 4 \times \mathrm{G} 5 \times \mathrm{G} 6$ & $.2551^{\mathrm{b}}$ \\
\hline
\end{tabular}

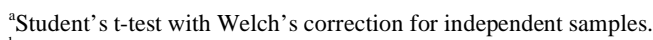

bone-way ANOVA.

Table 5. Comparison of pre- and post-treatment SR of enamel samples.

\begin{tabular}{|c|c|c|c|}
\hline Analysis Groups & \multicolumn{2}{|c|}{$\mathrm{SR}($ mean $\pm \mathrm{SD})$} & $\mathbf{P}$ \\
\hline G8 - $35 \%$ HP FN & $0.15 \pm 0.05$ & $0.10 \pm 0.04$ & $0.1102^{\mathrm{a}}$ \\
\hline G9 - 35\% HP FFA & $0.19 \pm 0.06$ & $0.19 \pm 0.08$ & $0.9651^{\mathrm{a}}$ \\
\hline G11 - 35\% HP w/ Ca FN & $0.16 \pm 0.03$ & $0.12 \pm 0.07$ & $0.3204^{\mathrm{a}}$ \\
\hline G12 - 35\% HP w/ Ca FFA & $0.19 \pm 0.10$ & $0.09 \pm 0.07$ & $0.1294^{\mathrm{a}}$ \\
\hline
\end{tabular}

${ }^{\text {a }}$ Student's t-test for paired samples. $\mathrm{SD}$, standard deviation.

Table 6. Difference in initial versus final SR of enamel samples.

\begin{tabular}{|c|c|c|}
\hline Analysis Groups & Mean Change in SR, Final - Initial, \pm SD & P \\
\hline \hline G7 $-35 \%$ HP S/F & $-0.09 \pm 0.11$ \\
\hline G8 - 35\% HP FN & $-0.05 \pm 0.05$ \\
\hline G9 - 35\% HP FFA & $0.0 \pm 0.10$ \\
\hline G10 - 35\% HP w/ Ca S/F & $-0.04 \pm 0.04$ \\
\hline G11 - 35\% HP w/ Ca NF & $-0.04 \pm 0.08$ \\
\hline G12 - 35\% HP w/ Ca FFA & $-0.10 \pm 0.12$ \\
\hline
\end{tabular}

ane-way ANOVA.

$\mathrm{SD}$, standard deviation.

Likewise, there was no significant overall effect of treatment group on SR variation between groups G7-G12 was found (Table 6).

\section{DISCUSSION}

A significant difference was observed between the action of fluoride gels and HP with and without calcium. The group treated with acidulated phosphate fluoride exhibited a reduction in average microhardness that may be attributed to the low $\mathrm{pH}$ of the fluoride gel. A qualitative study using SEM revealed that $35 \% \mathrm{HP}$ affects the morphology of human enamel, resulting in porosity, surface depressions, and irregularities, and that these changes were greater after application of $1.23 \%$ acidulated phosphate fluoride [35]. Morphological changes such as these may lead to a decrease in microhardness.

The degree of change in microhardness following treatment varied between groups treated with NF. The group bleached using $35 \% \mathrm{HP}$ exhibited greater variation than the 
group bleached with a combination of 35\% HP and calcium, possibly due to the restorative action of calcium ions. Previous studies have demonstrated that incorporation of calcium acid solutions can reduce the mineral loss in enamel by $50 \%$ [36]. Although bleaching agents are near neutral in $\mathrm{pH}$, [37] it is possible that the saturation of the enamel surface during bleaching is dependent on the agent used, and an ionic balance [38] promoting the deposition of calcium may be achieved at partially-saturated enamel surfaces [32].

The use of 35\% HP without fluoride resulted in a reduction in average KHN. Application of peroxides may reduce the concentration of calcium phosphate $[18,21,23,31,32$, $37,39]$ and fluoride in enamel $[21,32]$. In previously reported experiments, specimens treated with fluoridated bleaching agents experienced minor demineralization and erosion and decreases in microhardness without compromising the efficiency of clearance [24]. Preliminary studies have demonstrated that the addition of fluoride to $10 \%$ carbamide peroxide increased ion saturation during bleaching and reduced enamel demineralization [24, 32], confirming the results obtained in this study.

There was no significant difference in SR between samples treated with fluoride gels or hydrogen peroxide with or without calcium, or in the initial and final roughness of individual samples. This finding confirms the results of in vivo studies in which no differences were observed in the SR of enamel replicas treated using $38 \%$ HP or $35 \%$ carbamide peroxide [40]. However, other studies have reported an increase in enamel roughness after whitening [26,33], which promoted bacterial adhesion [33]. Topical application of fluoride has also been reported effective in reducing roughness after bleaching [41], contrary to the results obtained in this study.

The presence of saliva prevents the demineralizing effect of whitening gels in vivo better than in vitro [8]. The constant presence of saliva and fluoride may minimize changes in the enamel through the deposition of crystals of calcium fluoride, mitigating the effects of demineralization, prolonging the health of the tooth, and preventing changes that may damage the structure of bleached teeth [42]. Our methodology omitted the use of artificial saliva with the intention of assessing only the effects of topical fluoride gels on bleached enamel. It is suggested that further studies be performed with different fluoride therapies (such as daily use solutions).

\section{CONCLUSION}

1. Omission of fluoride treatment during bleaching was associated with a reduction in average enamel microhardness.

2. Acidulated phosphate fluoride combined with $35 \%$ hydrogen peroxide caused a reduction in average Knoop microhardness after bleaching.

3. Flugel neutral fluoride had a variable effect on microhardness when combined with calcium-containing $35 \%$ hydrogen peroxide.

4. No difference in surface roughness was observed with any combination of treatments.

\section{CONFLICT OF INTEREST}

The authors confirm that this article content has no conflict of interest.

\section{ACKNOWLEDGEMENTS}

This article was supported by Institutional Program for Scientific Initiation and Technological Development and Innovation Federal University of Pará (PROPESP / PIBIC / UFPA) and the FGM which provided the bleaching agents.

\section{REFERENCES}

[1] Haywood VB, Haymann HO. Nightguard vital bleaching. Quintessence Int 1989; 20(3): 173-6.

[2] Vieira GF, Arakaki Y, Caneppele TM. Spectrophotometric assessment of the effects of $10 \%$ carbamide peroxide on enameltranslucency. Braz Oral Res 2008; 22(1): 90-5.

[3] Watts A, Addy M. Tooth discolouration and staining: a review of the literature. Brit Dent J 2001; 190: 309-16.

[4] Meireles SS, Santos IS, Bona AD, Demarco FF. A double-blind randomized clinical trial of two carbamide peroxide tooth bleaching agents: 2-year follow-up. J Dent 2010; 38: 956-63.

[5] Joiner A. Whitening toothpastes: a review of the literature. J Dent 2010; 38: 17-24.

[6] Sulieman M, Addy M, MacDonald E, Rees JS. The effect of hydrogen peroxide concentration on the outcome of tooth whitening: an in vitro study. J Dent 2004; 32: 295-9.

[7] Hattab FN, Qudeimat MA, Al-Rimawi HS. Dental discoloration: an overview. J Esthet Dent 1999; 11(6): 291-310.

[8] Kim YS, Kwon HK, Kim BI. Effect of nano-carbonate apatite to prevent re-stain after dental bleaching in vitro. J Dent 2011; 39(9): 636-42.

[9] Singh RD, Ram SM, Shetty O, Chand P, Yadav R. Efficacy of casein phosphopeptide-amorphous calcium phosphate to prevent stain absorption on freshly bleached enamel: an in vitro study. J Conserv Dent 2010; 13: 76-9.

[10] Attin T, Kielbassa AM, Schwanenberg M, Hellwig E. Effect of fluoride treatment on remineralization of bleached enamel. J Oral Rehabil 1997; 24: 282-6.

[11] Bayrak S, Tunc ES, Sonmez IS, Egilmez T, Ozmen B. Effects of casein phosphopeptide-amorphous calcium phosphate (CPP-ACP) application on enamel microhardness after bleaching. Am J Dent 2009; 22: 393-6.

[12] de Oliveira R, Paes Leme AF, Giannini M. Effect of a carbamide peroxide bleaching gel containing calcium or fluoride on human enamel surface microhardness. Braz Dent J 2005; 16(2): 103-6.

[13] Giannini M, Silva AP, Cavalli V, Leme AF. Effect of carbamide peroxide-based bleaching agents containing fluoride or calcium on tensile strength of human enamel. J Appl Oral Sci 2006; 14: 82-7.

[14] Milnar FJ. Considering biomodification and remineralization techniques as adjuncts to vital tooth-bleaching regimens. Compend Contin Educ Dent 2007; 28: 234-6, 238-40.

[15] Attin T, Albrecht K., Becker K., Hannig C, Wiegand A. Influence of carbamide peroxide on enamel fluoride uptake. J Dent 2006; 34 : 668-75.

[16] Haywood VB. History, safety, and effectiveness of current bleaching techniques and aplplications of the nightguard vital bleaching technique. Quintessence Int 1992; 23: 471-88

[17] Zanet CG, Fava M, Alves LA. In vitro evaluation of the microhardness of bovine enamel exposed to acid solutions after bleaching. Braz Oral Res 2011; 25(6): 562-7.

[18] Buchalla W, Attin T. External bleaching therapy with activation by heat, light or laser: a systematic review. Dent Mater 2007; 23(5): 586-96.

[19] Justino LM, Tames DR, Demarco FF. In situ and in vitro effects of bleaching with carbamide peroxide on human enamel. Oper Dent 2004; 29(2): 219-25.

[20] Basting RT, Rodrigues AL Jr, Serra MC. The effects of seven carbamide peroxide bleaching agents on enamel microhardness over time. J Am Dent Assoc 2003; 134(10): 1335-42. 
[21] Attin T, Betke H, Schippan F, Wiegand A. Potential of fluoridated carbamide peroxide gels to support post-bleaching enamel rehardening. J Dent 2007; 35(9): 755-9.

[22] Maia E, Baratieri LN, Caldeira de Andrada MA, Monteiro S Jr, Vieira LC. The influence of two home-applied bleaching agents on enamel microhardness: an in situ study. J Dent 2008; 36(1): 2-7.

[23] Rodrigues JA, Marchi GM, Ambrosano GM, Heymann HO, Pimenta LA. Microhardness evaluation of in situ vital bleaching on human dental enamel using a novel study design. Dent Mater 2005; 21(11): 1059-67.

[24] Al-Salehi SK, Wood DJ, Hatton PV. The effect of 24h non-stop hydrogen peroxide concentration on bovine enamel and dentine mineral content and microhardness. J Dent 2007; 35(11): 845-50.

[25] Chen HP, Chang CH, Liu JK, Chuang SF, Yang JY. Effect of fluoride containing bleaching agents on enamel surface properties. J Dent 2008; 36(9): 718-25.

[26] Pinheiro JEC, Fidel RA, da Cruz Filho AM, Silva RG, Pécora JD. In vitro action of various carbamide peroxide gel bleaching agents on the microhardness of human enamel. Braz Dent J 1996; 7(2): $75-9$.

[27] Pinto CF, Oliveira R, Cavalli V, Giannini M. Peroxide bleaching agent effects on enamel surface microhardness, roughness and morphology. Braz Oral Res 2004; 18(4): 306-11

[28] Zantner C, Beheim-Schwarzbach N, Neumann K, Kielbassa AM. Surface microhardness of enamel after different home bleaching procedures. Dent Mater 2007; 23(2): 243-50.

[29] Sulieman M, Addy M, Macdonald E, Rees JS. A safety study in vitro for the effects of an in-office bleaching system on the integrity of enamel and dentine. J Dent 2004; 32(7): 581-90.

[30] Joiner A. Review of the effects of peroxide on enamel and dentine properties. J Dent 2007; 35(12): 889-96.

[31] Joiner A, Thakker G, Cooper Y. Evaluation of a $6 \%$ hydrogen peroxide tooth whitening gel on enamel and dentine microhardness in vitro. J Dent 2004; 32(1): 27-34.
[32] PotocniK I, Kosec L, Gaspersic D. Effect of $10 \%$ carbamide peroxide bleaching gel on enamel microhardness, microstructure, and mineral content. J Endod 2000; 26(4): 203-6.

[33] Bayrak S, Tunc ES, Sonmez IS, Egilmez T, Ozmen B. Effects of casein phosphopeptide-amorphous calcium phosphate (CPP- ACP) application on enamel microhardness after blenching. Am J Dent 2009; 22(6): 393-6.

[34] Hosoya N, Honda K, Ino F, Arai T. Changes in enamel surface roughness and adhesion of Streptococcus mutans to enamel after vital bleaching. J Dent 2003; 31(8): 543-8.

[35] Villena RS, Tenuta LM, Cury JA. Effect of APF gel application time on enamel demineralization and fluoride uptake in situ. Braz Dent J 2009; 20(1): 37-41

[36] Ferreira Sda S, Araújo JL, Morhy ON, Tapety CM, Youssef MN, Sobral MA. The effect of fluoride therapies on the morphology of bleached human dental enamel. Microsc Res Tech 2011; 74(6): 512-6

[37] Hughes JA, West NX, Parker DM, van den Braak MH, Addy M. Effects of $\mathrm{pH}$ and concentration of citric, malic and lactic acids on enamel, in vitro. J Dent 2000; 28(2): 147-52.

[38] Price RB, Sedarous M, Hiltz GS. The $\mathrm{pH}$ of tooth-whitening products. J Can Dent Assoc 2000; 66(8): 421-6.

[39] Gao XJ, Elliott JC, Anderson P. Scanning and contact microradiographic study of the effect of degree of saturation on the rate of enamel demineralization. J Dent Res 1991; 70(10): 1332-7.

[40] McCracken MS, Haywood VB. Demineralization effects of 10 percent carbamide peroxide. J Dent 1996; 24(6): 395-8.

[41] Cadenaro M, Breschi L, Nucci C, et al. Effect of two in-office whitening agents on the enamel surface in vivo: a morphological and non-contact profilometric study. Oper Dent 2008; 33(2): 12734.

[42] Lewinstein I, Fuhner N, Churaru N, Cardash H. Effect of different peroxide bleaching regimens and subsequent fluoridation on the hardness of human enamel and dentin. J Prosthet Dent 2004; 92(4): $337-42$.

(C) China et al.; Licensee Bentham Open.

This is an open access article licensed under the terms of the Creative Commons Attribution Non-Commercial License (http://creativecommons.org/licenses/by-nc/3.0/) which permits unrestricted, non-commercial use, distribution and reproduction in any medium, provided the work is properly cited. 